\title{
BIOEQUIVALENCE OF TWO FORMULATIONS OF GLICLAZIDE IN A RANDOMIZED CROSSOVER STUDY IN HEALTHY CAUCASIAN SUBJECTS UNDER FED CONDITION
}

\author{
DIANA IOANA POP ${ }^{1,2}$, MONICA OROIAN ${ }^{1,2}$, SANDEEP BHARDWAJ $^{2}$, ADRIANA \\ MARCOVICI $^{2}$, ARSHAD KHUROO $^{3}$, RAVI KOCHHAR ${ }^{4}$, LAURIAN VLASE $^{1}$ \\ ${ }^{I}$ Department of Pharmaceutical Technology and Biopharmaceutics, Faculty of Pharmacy, "Iuliu Hatieganu" University of \\ Medicine and Pharmacy, Cluj-Napoca, Romania \\ ${ }^{2}$ Clinical Pharmacology and Pharmacokinetics Department, Terapia SA - a Sun Pharma Company, Cluj-Napoca, Romania \\ ${ }^{3}$ Clinical Pharmacology and Pharmacokinetics Department, Gurugram, India \\ ${ }^{4} R \& D$ Formulation Development, Gurugram, India
}

*corresponding author: diana.pop@umfcluj.ro

\begin{abstract}
This study was aimed to assess the bioequivalence of a test product, Gliclazide $60 \mathrm{mg}$ modified release tablets (Ranbaxy Laboratories Limited, now Sun Pharmaceutical Industries, India) and a reference product Diamicron ${ }^{\circledR} 60 \mathrm{mg}$ modified release tablets (Les Laboratoires Servier Industrie, France) in 26 healthy Caucasian volunteers under fed condition. The design of the study was single-dose, two-treatment, two-period, and two-sequence crossover study in fed condition with a washout period of 21 days. Blood samples were collected for a period of $96 \mathrm{~h}$ after drug administration in each period. Gliclazide plasma concentrations were determined by a LC-MS/MS method. Pharmacokinetic analysis used a non-compartmental model. The logarithmically transformed data of $\mathrm{C}_{\max }$ and AUCs were analysed using ANOVA. The $90 \%$ confidence intervals were within the acceptance range of $80.00-125.00 \%$ and there is no significant difference in pharmacokinetic characteristics between the products. The investigated products are bioequivalent under fed condition.
\end{abstract}

\section{Rezumat}

Acest studiu a urmărit să evalueze bioechivalența unui produs test, Gliclazide $60 \mathrm{mg}$ comprimate cu eliberare modificată (Ranbaxy Laboratories Limited, în prezent Sun Pharmaceutical Industries, India) și un produs de referință, Diamicron ${ }^{\mathbb{B}} 60 \mathrm{mg}$ comprimate cu eliberare modificată (Les Laboratoires Servier Industrie, Franța) pe 26 de voluntari caucazieni sănătoși în condiții post-prandiale. Modelul studiului a fost unul încrucişat cu doză unică, două tratamente, două perioade şi două secvențe, în condiții post-prandiale, cu o perioadă de eliminare de 21 de zile. Probele de sânge au fost recoltate într-un interval de 96 ore după administrarea medicamentului în fiecare perioadă. Concentrațiile plasmatice ale gliclazidei au fost determinate printr-o metodă LC-MS/MS. Analiza farmacocinetică a utilizat un model non-compartimental. Datele transformate logaritmic ale $C_{\max }$ și ASC au fost analizate utilizând ANOVA. Intervalele de încredere $90 \%$ se încadrează în intervalul acceptat de 80,00 - 125,00\% și nu există diferențe semnificative în ceea ce privește caracteristicile farmacocinetice între produse. Produsele investigate sunt bioechivalente în condiții post-prandiale.

Keywords: pharmacokinetics, bioequivalence, gliclazide, modified release tablets

\section{Introduction}

The incidence of type 2 diabetes increased dramatically due to urbanization, aging of population, changes in diet, obesity, sedentary lifestyle. Diabetes is associated with a large number of chronic complications $[6,10]$. Treatment of type 2 diabetes mellitus according to the therapeutic guidelines developed by various international organizations may include non-pharmacological treatment (diet and exercise) and medication [10]. Oral hypoglycaemic agents and insulin are generally available in only few low-income countries. For improvement of equitable access, there is need for policy and programme interventions $[10,11]$.
The most frequently used oral hypoglycaemic agents are sulfonylureas. Trials of gliclazide modified release tablets support its use as first-line treatment in type 2 diabetes, including to elderly, obese and mild-tomoderate renal insufficient patients. The compliance to treatment is significantly improved due to the simplicity of the dose regimen and its tolerance and efficacy, especially when T2DM is associated with other comorbidities $[1,2]$.

As a mechanism of action, gliclazide decreases the blood glucose levels by stimulating the secretion of insulin from the $\beta$-cells of the Langerhans islets. Gliclazide has high affinity with strong selectivity and it is reversible bound to the $\beta$-cell KATP channels. Gliclazide has low affinity for vascular and cardiac 
FARMACIA, 2018, Vol. 66, 4

KATP channels. It was shown that the C-peptide secretion and the increased postprandial insulin persists even after two years of treatment. It was shown that gliclazide also has haemovascular properties and extra-pancreatic effects [4].

There have been developed gliclazide modified release dosage forms that are designed to activate the drug release by formation of a gel as a result of the hydration of the tablet. Gliclazide modified release forms have shown to have reproducible and predictable release of Gliclazide and effective plasma concentrations are maintained over a 24 hour period. From sixth to twelfth hour after drug intake the plasma levels show a plateau-shaped curve. It was reported a low intraindividual variability. The absorption of gliclazide is rapid and complete. It was reported that the degree or rate of absorption is not affected by food intake [8]. Gliclazide has a low apparent volume of distribution and high degree of binding to proteins (approximately 94\%) [9].

Gliclazide is extensively metabolized, mainly in the liver. Resulted metabolites and conjugates are excreted by kidneys (60 - 70\%) and by faeces (10 - 20\%). In urine can be found $<1 \%$ of the unchanged drug. There has not been found any active metabolites in plasma. Transporters are not involved in gliclazide disposition. [3, 8].

Gliclazide is metabolized by cytochrome P450 2C9 (CYP2C9), polymorphic enzyme, with possible contributions of CYP2C19 and CYP2C18. The individual differences observed in the gliclazide's hypoglycaemic effects could be a result of CYP2C9 polymorphism or additional pharmacodynamic factors [3].

Gliclazide's elimination half-life was reported between 8.1 and 20.5 hours [9].

The dose and the area under the concentration curve relationship is linear for a dose ranging up to $120 \mathrm{mg}$ [8].

After medium-term treatment (10 weeks) with gliclazide modified release formulations given once-daily, the glycaemic profile was improved over 24 hours with a decrease of mean $\mathrm{HbA} 1 \mathrm{c}$ of $1 \%$. Also, it was noted an improvement of patient compliance [5].

There has been developed a new generic formulation. The bioequivalence will be assessed for this product with the already marketed product.

\section{Materials and Methods}

The clinical study protocol was approved by National Agency for Medicines and Medical Devices, Romania and the Ethics Committee of the "Iuliu Hațieganu" University of Medicine and Pharmacy Cluj-Napoca, Romania.

The study was performed at the Clinical Pharmacology and Pharmacokinetics Department of Terapia SA, Romania.
This clinical study was conducted in accordance with US 21 CFR Part 320, the ICH E6 (R1), Declaration of Helsinki and the "Guideline on the Investigation of Bioequivalence" by the European Agency for the Evaluation of Medicinal Products.

The study was conducted as an open label, balanced, randomized, two-treatment, two-period, two-sequence, single-dose, crossover bioequivalence study comparing the two treatments (one test and one reference formulation as modified release tablets containing Gliclazide $60 \mathrm{mg}$ ) in fed condition. The washout period was 21 days.

Each subject was informed about all the study details, including rights, obligations and possible side effects. A written consent has been obtained from each volunteer prior to any screening procedures.

The Investigator included in the study only healthy volunteers after examining their health on the basis of medical history, physical examination, ECG and routine blood and urine tests. Volunteers were also tested for drugs of abuse and alcohol and in case of female volunteers, for pregnancy. The volunteers were asked about consumption of any pharmacological agent and/or dietary product and it was evaluated the risk of drug interaction.

Test product was a new generic modified release formulation containing Gliclazide $60 \mathrm{mg}$ developed by Ranbaxy Laboratories Limited, now Sun Pharmaceutical Industries, India and the reference product was Diamicron $^{\circledR}$ modified release tablets (containing gliclazide $60 \mathrm{mg}$ ) manufactured by Les Laboratoires Servier Industrie, France.

In each period of the study the subjects received alternatively, according to the generated randomization list, the test formulation $(\mathrm{T})$ or the reference formulation (R).

Following a fasting period of at least 10 hours, the subjects started the recommended high-fat high-calorie standard meal, 30 minutes prior to administration of the drug product. The drug product was administered with $240 \mathrm{~mL}$ of $20 \%$ glucose solution. During the first 4 hours post dose at every 15 minutes it was administered approximately $60 \mathrm{~mL}$ of $20 \%$ glucose solution. The fasting period continued for 4 hours post-dose. Water was also restricted 1 hour before drug administration until 2 hours post-dose. Subjects received standard meals, identical for both the periods during the housing period.

Throughout the study, the subjects were monitored for adverse events and vital signs (sitting blood pressure, radial pulse and axillary body temperature) and blood glucose levels were measured periodically according to the study protocol. During each period of the study, principal investigator/subinvestigator was available for at least 24 hour post-dose at the investigation site. The clinical examination, urine analysis, biochemistry and haematology tests and pregnancy test (in case 
of females) were repeated for the safety assessment at the end of the study.

Blood samples were collected in $\mathrm{K}_{3}$ EDTA vacutainers: pre-dose and at $1,2,3,4,5,6,7,8,9,10,11,12,13$, $14,15,16,20,24,36,48,72$ and 96 hours post-dose in each period. The samples were collected either through indwelling cannula or through a new vein puncture.

Blood samples were centrifuged for $15 \mathrm{~min}$, under refrigeration, at $4000 \mathrm{rpm}$ for plasma separation which was kept at $-50^{\circ} \mathrm{C}$ until assay. For the determination of Gliclazide in plasma it was used a validated LCMS/MS method using Gliclazide D4 as internal standard.

The relationship between concentration and peak area was found to be linear in the range of $5.00 \mathrm{ng} / \mathrm{mL}$ to $5016.48 \mathrm{ng} / \mathrm{mL}$. The limit of quantification was $5.00 \mathrm{ng} / \mathrm{mL}$ [7].

HPLC Agilent 1200 from Agilent Technologies, MS API 3200 from Applied Biosystem MDS SCIEX and Analyst software version 1.4.2 were used for sample analysis and data processing. All the sample processing was done under low light conditions. Retention times were for Gliclazide and Gliclazide D4 between 0.3 2.0 minutes [7].

During validation it has been reported a between-run precision of $1.83 \%$ to $4.69 \%$, between-run accuracy of $90.53 \%$ to $110.14 \%$, within-run precision of $0.96 \%$ to $4.38 \%$ and a within-run accuracy of $89.10 \%$ to $114.98 \%$ [7].

The noncompartmental pharmacokinetic analysis was performed for Gliclazide using WinNonlin ${ }^{\circledR}$ PK software version 5.2 and the following parameters were calculated: $\mathrm{C}_{\max }, \mathrm{T}_{\max }, \mathrm{AUC}_{0-\mathrm{t}}, \mathrm{AUC}_{0-\infty}, \mathrm{AUC} \%$ Extrap and $\mathrm{T}_{1 / 2}$.

The statistical analysis was performed for log-transformed pharmacokinetic parameters $\left(\mathrm{C}_{\max }, \mathrm{AUC}_{0-\mathrm{t}}\right.$ and $\left.\mathrm{AUC}_{0-\infty}\right)$ using SAS software version 9.1.3. The analysis used Type III sum of squares from ANOVA.

Ratios of means were calculated using the antilog of the differences of LSM for log-transformed $\mathrm{C}_{\max }$, $\mathrm{AUC}_{0-\mathrm{t}}$ and $\mathrm{AUC}_{0-\infty}$. For pharmacokinetic parameters $\mathrm{C}_{\max }$ and $\mathrm{AUC}_{0-\mathrm{t}}$ of log-transformed data the confidence interval $90 \%$ for the test $(\mathrm{T})$ and reference $(\mathrm{R})$ product ratio averages should be in $80 \%-125 \%$ interval.

\section{Results and Discussion}

26 Caucasian subjects were enrolled in the study and 23 subjects finalized the study. The mean age, mean weight, mean height and mean BMI of the subjects completing the study were 25 years (range 19 to 35 years), $74 \mathrm{~kg}$ (range 56 to $92 \mathrm{~kg}$ ), $180 \mathrm{~cm}$ (range 166 to $195 \mathrm{~cm}$ ), $22.9 \mathrm{~kg} / \mathrm{m}^{2}$ (18.6 to $28.7 \mathrm{~kg} / \mathrm{m}^{2}$ ), respectively.

In this study there were reported the following notserious adverse events: excoriations, hypoglycaemia, diarrheic syndrome, increased BUN, leukocyturia, increased ALT, increased direct bilirubin, increased total bilirubin, decreased serum glucose, haematuria and proteinuria.

The plot of Gliclazide mean plasma concentration versus time under the fed condition is showed in Figure 1 and pharmacokinetic characteristics are summarized in Table I. The products have similar values for $\mathrm{C}_{\max }$ and $\mathrm{AUC}_{0-\mathrm{t}}$

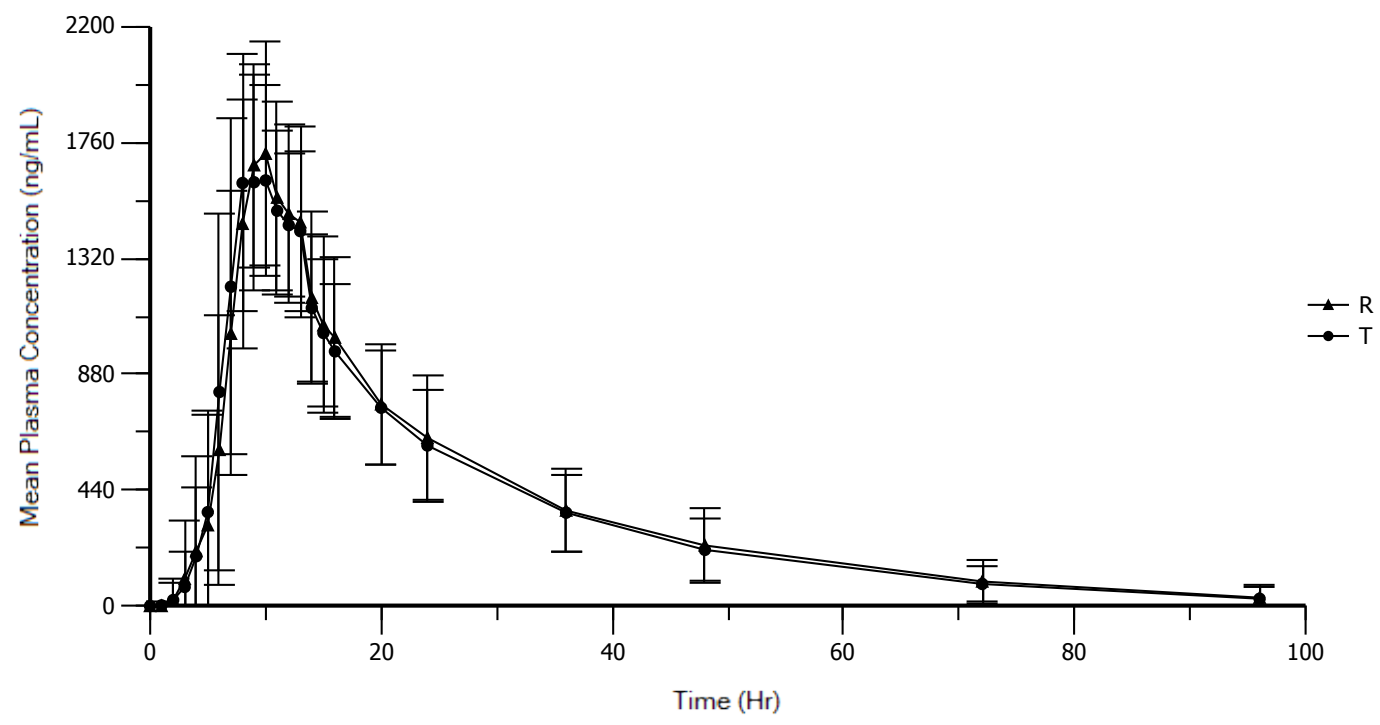

Figure 1.

Mean plasma concentration of gliclazide after administration of test product (Gliclazide $60 \mathrm{mg}$ modified release tablets), and the reference product (Diamicron ${ }^{\circledR}$ modified release tablets), in 23 volunteers under fed condition. 
Pharmacokinetic characteristics of Gliclazide in 23 volunteers following administration of Gliclazide modified release tablets $60 \mathrm{mg}$ under fed condition

\begin{tabular}{|c|c|c|c|c|c|c|c|c|c|c|c|c|}
\hline \multirow[t]{2}{*}{\begin{tabular}{|c|}
$\begin{array}{c}\text { Pharmacokinetic } \\
\text { Parameters }\end{array}$ \\
\end{tabular}} & \multicolumn{2}{|c|}{$\underset{(\mathrm{ng} / \mathrm{mL})}{\mathrm{C}_{\max }}$} & \multicolumn{2}{|c|}{$\begin{array}{c}\mathrm{AUC}_{0-\mathrm{t}} \\
\left(\mathrm{hr} \mathbf{r}^{*} \mathrm{ng} / \mathrm{mL}\right)\end{array}$} & \multicolumn{2}{|c|}{$\begin{array}{c}\mathrm{AUC}_{0-\infty} \\
(\mathrm{hr} * \mathrm{ng} / \mathrm{mL})\end{array}$} & \multicolumn{2}{|c|}{$\begin{array}{c}\text { AUC \% Extrap } \\
\text { (hr*ng/mL) }\end{array}$} & \multicolumn{2}{|c|}{$\begin{array}{l}\mathrm{T}_{1 / 2} \\
(\mathrm{hr})\end{array}$} & \multicolumn{2}{|c|}{$\begin{array}{l}T_{\max } \\
\text { (hr) }\end{array}$} \\
\hline & $\mathbf{R}$ & $\mathbf{T}$ & $\mathbf{R}$ & $\mathbf{T}$ & $\mathbf{R}$ & $\mathbf{R}$ & $\mathbf{R}$ & $\mathbf{T}$ & $\mathbf{R}$ & $\mathbf{T}$ & $\mathbf{R}$ & $\mathbf{T}$ \\
\hline Mean & 1862.9 & 1844.3 & 35205.1 & 34156.0 & 36772.0 & 35702.5 & 3.9 & 4.2 & 16.1 & 15.8 & \begin{tabular}{|l|l|}
9.2 \\
\end{tabular} & 9.2 \\
\hline SD & 401.0 & 405.2 & 12096.2 & 11322.4 & 13247.8 & 12056.7 & 1.8 & 2.3 & \begin{tabular}{|l|}
4.5 \\
\end{tabular} & 4.6 & 1.8 & 2.1 \\
\hline Min & 1131.8 & 1123.9 & 15151.0 & 15765.0 & 15619.4 & \begin{tabular}{|l|}
16381.3 \\
\end{tabular} & 2.2 & 1.5 & \begin{tabular}{|l|l}
9.1 \\
\end{tabular} & 9.1 & \begin{tabular}{|l|}
6.0 \\
\end{tabular} & 6.0 \\
\hline Max & 2676.3 & 2698.8 & 63649.8 & 54940.3 & 68016.9 & 60225.1 & 9.5 & 10.4 & 27.6 & 29.4 & 13.0 & 13.0 \\
\hline CV\% & 21.5 & 22.0 & 34.4 & 33.2 & 36.0 & 33.8 & 47.0 & 55.2 & 27.7 & 29.0 & 19.9 & 22.9 \\
\hline Median & & & & & - & & & & & & \begin{tabular}{|l|}
9.0 \\
\end{tabular} & 8.0 \\
\hline
\end{tabular}

T represents Test Product which is Gliclazide $60 \mathrm{mg}$ modified release tablets. R represents Reference Product which is Diamicron ${ }^{\mathbb{R}} 60 \mathrm{mg}$ modified release tablets

The ratios of LSM (with $90 \%$ confidence intervals) for $\mathrm{C}_{\max }, \mathrm{AUC}_{0-\mathrm{t}}$ and $\mathrm{AUC}_{0-\infty}$ for Gliclazide were 99.04\% (93.17\% - 105.28\%), 97.43\% (93.13\% $101.93 \%)$, respectively $97.78 \%$ (93.48\% - 102.27\%). The reported adverse events in this study are unlikely to have any impact on the subjects' safety.

The mean values obtained for the pharmacokinetic parameters were comparable for the reference and test product. The test product gave slightly lower $\mathrm{C}_{\max }$ and AUC than the reference product, however not statistically significant. The mean $\mathrm{T}_{\max }$ value $(9.2 \mathrm{hr})$ and range ( $6 \mathrm{hr}-13 \mathrm{hr}$ ) was same for the test product and reference product with median $\mathrm{T}_{\max }$ of $9 \mathrm{hr}$ for reference product and $8 \mathrm{hr}$ for test product. The $\mathrm{T}_{\max }$ values obtained from this study were similar and comparable to values earlier reported [8].

The $T_{1 / 2}$ values of the test product $(15.8 \mathrm{hr})$ and reference product (16.1 hr) were similar and comparable to those values reported previously [9].

For all evaluated pharmacokinetic parameters there have not been found any significant difference between both products under fed condition.

Test $(\mathrm{T})$ and reference $(\mathrm{R})$ product ratio averages and the $90 \%$ confidence intervals for $\log$ transformed obtained values for pharmacokinetic parameters $\mathrm{C}_{\max }$ and $\mathrm{AUC}_{0-\mathrm{t}}$ were in the acceptance range of 80.00 $125.00 \%$.

Based on these results, it was concluded that Gliclazide $60 \mathrm{mg}$ modified release tablets manufactured by Ranbaxy Laboratories Ltd, now Sun Pharmaceutical Industries, India is bioequivalent with Diamicron ${ }^{\circledR}$ modified release tablets (containing gliclazide $60 \mathrm{mg}$ ) manufactured by Les Laboratoires Servier Industrie, France under fed condition in healthy, adult subjects and can be interchangeable. Considering the results of the study by registration of generic products more patients would have access to appropriate treatment. Effective concentrations are maintained during a period of 24 hours by using modified release tablets and the patient compliance to treatment is improved.

\section{Conclusions}

Gliclazide 60 mg modified release tablets manufactured by Ranbaxy Laboratories Ltd, now Sun Pharmaceutical Industries, India and Diamicron ${ }^{\circledR}$ modified release tablets (containing gliclazide $60 \mathrm{mg}$ ) manufactured by Les Laboratoires Servier Industrie, France are bioequivalent in healthy, adult, human subjects under fed condition.

\section{Conflict of interest}

The authors declare no conflict of interest.

\section{References}

1. Crepaldi G, Fioretto P, Gliclazide modified release: its place in the therapeutic armamentarium. Metabolism, 2000; 49(10 Suppl2): 21-25.

2. Tilea I, Petra D, Voidazan S, Ardeleanu E, Varga A, Treatment adherence among adult hypertensive patients: a croos-sectional retrospective study in primary care in Romania. Patient Prefer Adher., 2018; 12: 625-635.

3. Elliot DJ, Suharjono, Lewis BC, Gillam EM, Birkett DJ, Gross AS, Miners JO, Identification of the human cytochromes $\mathrm{P} 450$ catalysing the rate-limiting pathways of gliclazide elimination. Br J Clin Pharmacol., 2007; 64(4): 450-457.

4. Gribble FM, Ashcroft FM, Differential sensitivity of beta-cell and extrapancreatic K(ATP) channels to gliclazide. Diabetologia , 1999; 42(7): 845-848.

5. Guillausseau PJ, Greb W, 24-hour glycemic profile in type 2 diabetic patients treated with gliclazide modified release once daily. Diabetes Metab, 2001; 27(2 Pt1): 133-137.

6. Ionescu C, Lichiardopol R, Dobjanschi C, Type 2 diabetes-Therapeutic guide for general practitioners. RJDNMD, 2006; 13(4): 274-278.

7. Pop DI, Oroian M, Bhardwaj S, Marcovici A, Khuroo A, Kochhar R, Vlase L, Bioequivalence of two formulations of gliclazide in a randomized crossover study in healthy Caucasian subjects under fasting conditions. Clin Pharm Drug Dev., 2018; 00(0): 1-6.

8. Rojanasthien N, Autsavakitipong T, Kumsorn B, Manorot M, Teekachunhatean S, Bioequivalence study of modified-release gliclazide tablets in healthy volunteers. ISRN Pharmacol., 2012; 2012: 1-6. 
FARMACIA, 2018, Vol. 66, 4

9. Sakar A, Tiwari A, Bhasin PS, Pharmacological and pharmaceutical profile of gliclazide: A review. J Appl Pharm Sci., 2011; 1(9): 11-19.

10. World Health Organization. Global report on diabetes. WHO 2016
11. Teodoru I, Rusu E, Radulian G, A 4 years study in diabetic chronic kidney disease patients on ketoaminoacids treatment in Bucharest. Results after 1-year follow-up. Farmacia, 2018; 66(2): 296-301. 